\title{
Design And Build Water Wheel Knock Down System (W2kds) As The Prime Mover Of Rice Milling
}

\author{
Asep Neris Bachtiar ${ }^{1}$, Ahmad Fauzi Pohan ${ }^{2}$ \\ $\left\{{ }^{1}\right.$ asepnb1963@yahoo.co.id $\}$ \\ ${ }^{1,2}$ Departement of Mining Engineering, STTIND, Padang, Indonesia
}

\begin{abstract}
This research continued the success of previous research which has managed to build a Water Wheel Knock Down System (W2KDS) which can be devided into small components for easy carrying, in term of installing and testing it to an isolated location. Based on the success of the research were inspired to developed this W2KDS system that is capable of moving the W2KDS build a rice milling. The method of this research is a survey to the location, planning systems and components, the manufacturing process of components and assembly W2KDS and then have it tested. The percentage of prime mover and transmission efficiency shows $79 \%, 94 \%$ respectively and productivity rice milling is $144 \mathrm{~kg} /$ hour. This result shows the quality of prime mover and transmission are made is can be proud of. For the production of rice milling is quite satisfactory.
\end{abstract}

Keywords: Water Wheel. Knock Down. Prime Mover. Rice Milling.

\section{Introduction}

Based on data from the Regional Development Planning Board West Sumatera Regency. The using of a wooden waterwheel rice milling year to year is decreased (Table 1). It is because of limitations the source of the raw material wood, and then we are motivated to make waterwhell permanent system from steel plate, and the researchers have been successfully produced 4 water wheel permanent system for installation and measurement in location,because of its big size and heavy as shown in figure1.

As the location is isolated, we managed to build a W2KDS from its small components. The installation is carried out in the research area as shown in figure. 2 and figure. 3.The Assembly process in the W2KDS test site is easier than W2KDS, which is only spend three hours. Its symmetrical construction, sturdy and compact so that when you get a collision water when tested a full stable and solid. Measurement results show that W2KDS accomplishment was satisfactory, the efficiency of W2KDS reaches $76 \%$ and the efficiency of the transmission of two levels of about $92 \%$. Next up from the success of this, we are inspired to develop the W2KDSinto two functions, the first at night as a power plant and the second at day as the prime mover of rice milling. 


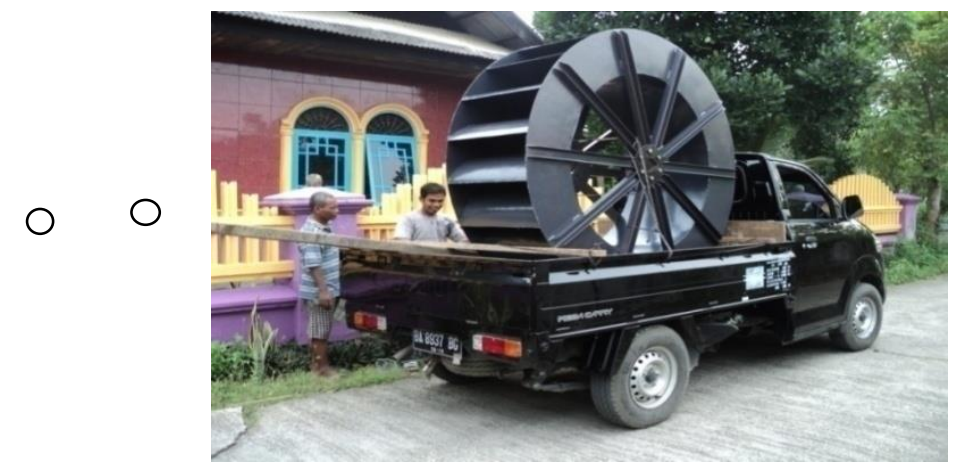

Fig.1. The permanent water wheel is big size be an obstacle when bring to the location.

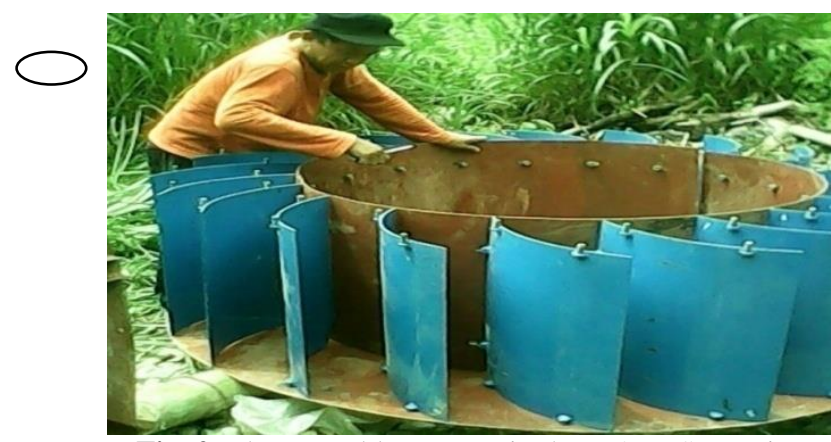

Fig. 2. The assembly process in the W2KDS test site

This is a study of the development of renewable energy generation that is realistic considering the success of previous research that inspired to further utilize the potential of picohydro scale water in rural areas in West Sumatra. We hope that with the W2KDS technology revolution will add enthusiasm to all of us to use the potential of renewable energy in the village as a potential multi-function energy source.

Table 1. Use of a wooden water wheel as the prime mover of rice milling

\begin{tabular}{cc}
\hline Year & Units \\
\hline 1974 & 4082 \\
1979 & 1619 \\
1986 & 560 \\
\hline
\end{tabular}

Source: The Regional Development Planning Board West Sumatera Regency, 1986. 


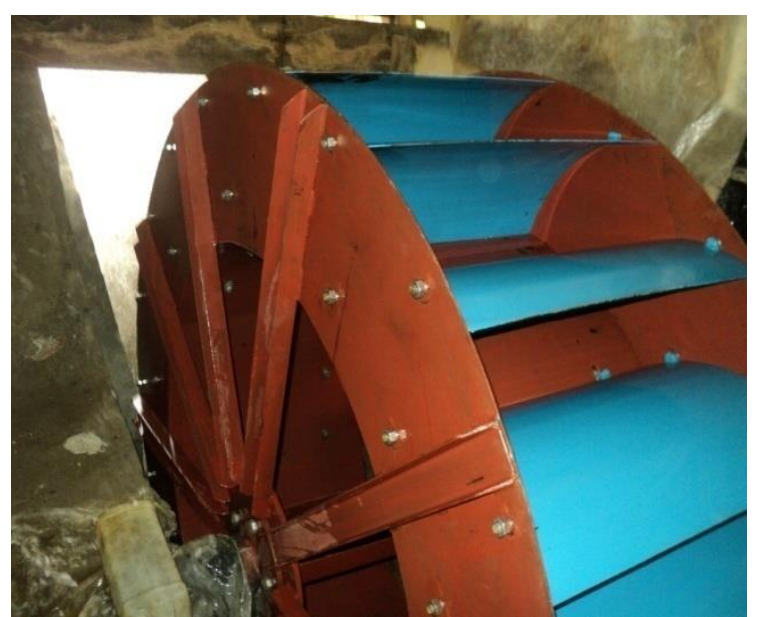

Fig. 3. W2KDS after assembled and mounted on a cradle

Williamson et al(2011) managed to provide important information on the specifications of various primer mover as the picohydro power plants (power $<10 \mathrm{~kW}$ ) including all types of water wheel. They have successfully recommended the terms of operation of each turbine to improve the efficiency of the low head turbine. Figure 4 (a) shows that the reaction turbine has superior power generation capability. If the head is increased, then the power density and water wheel will increase too, but screw turbine decreases. Solution is by increasing the incoming volume of the Jet Pelton Wheel and the Jet Turgo Turbine is to change the size of the pipe solid. Figure 4 (c) shows The efficiency of the Single Jet Turgo Turbine is superior to that of other turbines. Jet Pelton Wheel doesn't require a gearbox system transmission. If the value increases, the result will increase the speed runner too. Figure 5. shows the variation of the value for the head range $(0,5$ until $3,5 \mathrm{~m})$, and the use of the propeller with draft tube (DT) is most suitable for heads between 0.5 and $1.5 \mathrm{~m}$, while for the best Single Jet Turgo Turbine solution is operated for head above $1.5 \mathrm{~m}$. Propeller turbine and Radial turbine with draft tube (DT) have almost the same weighted score with a Single Jet Turgo Turbine for heads above $1.5 \mathrm{~m}$. The results of the analysis of these graph (figure 5) provide some recommendations from operation of the turbine on the low head and for a commercial power plant can develop a Propeller Turbine with DT. The surprising result is that the Jet Turgo Turbine, where the Jet Turgo Turbine is usually only used on the middle head(1.5 - 2.5 m)turned out to be operated on the high head (Paish, 2002). However, Harvey (1993) explains that the Jet Pelton Wheel, and the Jet Turgo Turbine can be operated on the low head with the consequence of the runner speed be low.

This research is part of a project development potential low head water system for off-grid picohydro system. The selection of the turbines is a initial stage of strategic research to determine the next appropriate technological choices. This paper presents a method of determining low head pico hydro power plant systems with multi-criteria analysis both of quantitatively and qualitatively. Using this method, the Propeller Turbine is equipped with DT and the Single Jet Turgo Turbines is the best solution as a prime mover. 

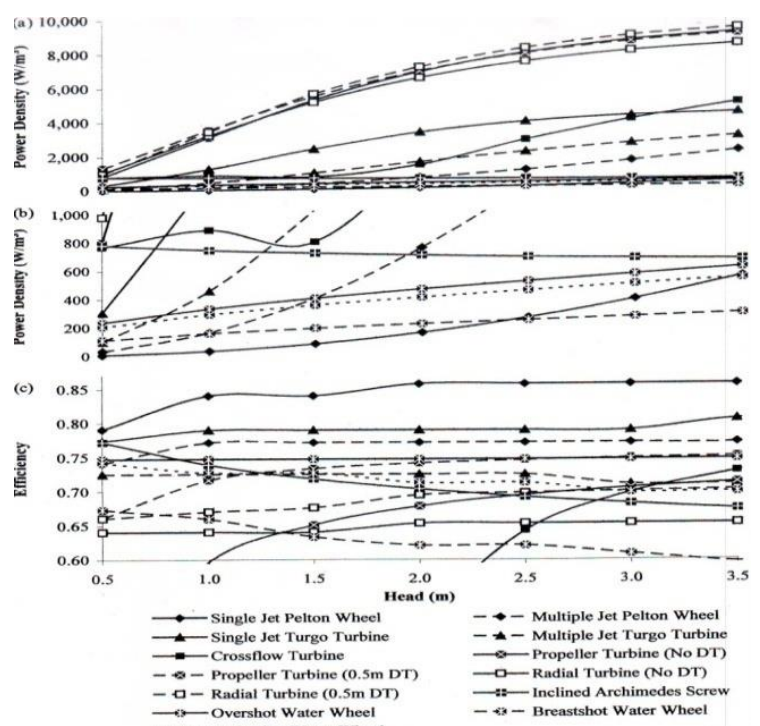

Fig. 4. The output of the quantitative analysis: (a) power density,(b) density power magnified in low head (c) variations in efficiency over the range of 0.5 to $3.5 \mathrm{~m}$ head $\mathrm{m}$, (DT $=$ Draft Tube)

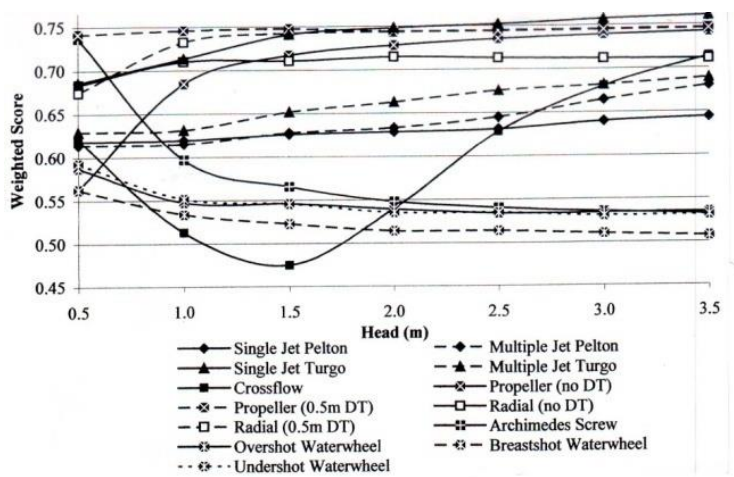

Fig. 5. Weighted for turbine selection to span 13 head $0.5 \mathrm{~m}$ to $3.5 \mathrm{~m}$.

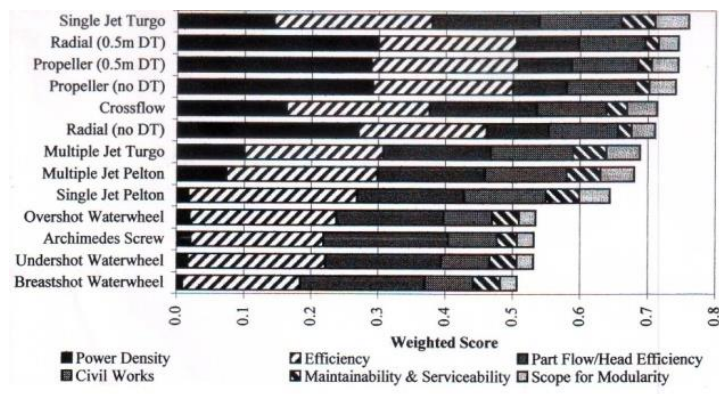

Fig. 6. The value of the score on head $3.5 \mathrm{~m}$ for turbine selection with 13 product from each of the different selection criteria. 


\section{Method}

The type of research that will be carried out is experimental research with research material including survey data phase to test location, designing, drawing work, manufacturing process, transportation, assembling and testing phase. The type of data that will be the reference is the primary data from observation of W2KDS-rice milling system such as figure 7. and figure 8 . The data are then processed through formulas of machine element planning and the big picture that will be used as guidance in the manufacturing process to realize the component W2KDStwo complete function and assemble it into a system W2KDS - production machines (rice milling and generator/power plant) are ready to test. The testing is the final stage carried out in the field to determine the achievement of W2KDS system includes the efficiency of prime mover, transmission system efficiency, and productivity of rice milling production machine.

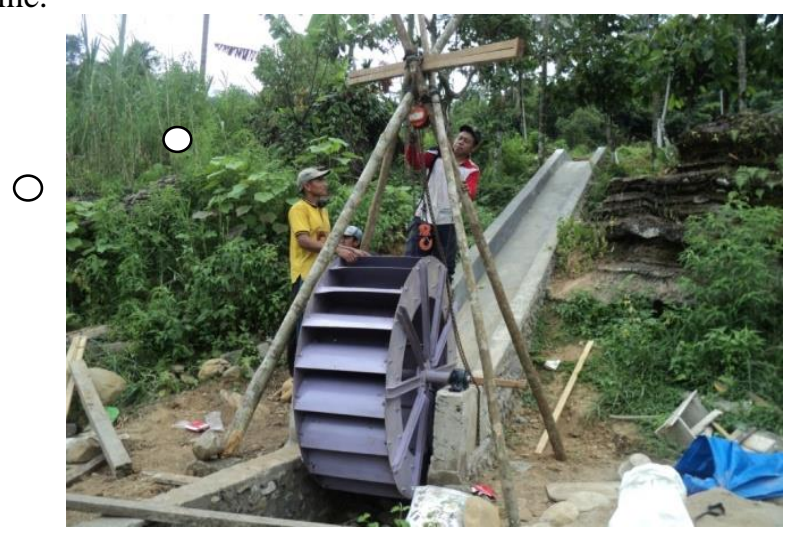

Fig. 7. Installation of the W2KDS on the ground

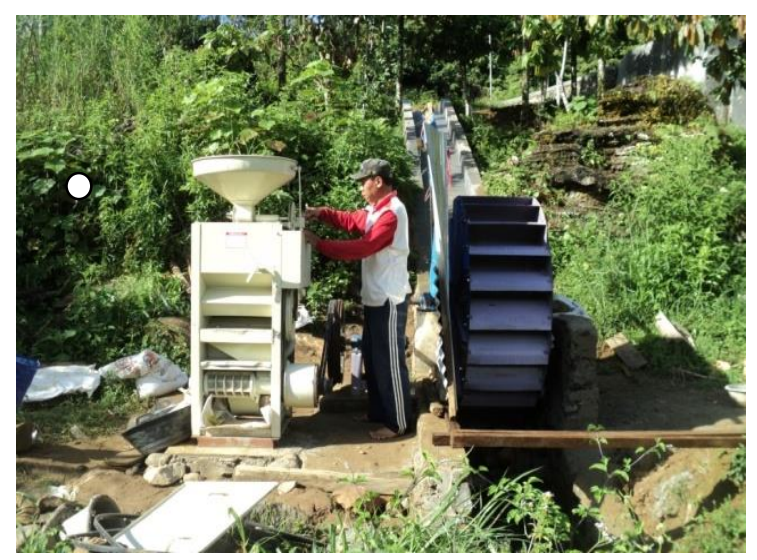

Fig. 8. W2KDS efficiency testing process 


\section{Result}

\subsection{Observation of The Characteristics of Excellence W2KDS}

The initial hypothesis of expected W2KDS have many advantages compared to water wheel permanent system that we made, there are seven characteristic to assess the difference between a W2KDS compare to Water Wheel Permanent System. the process created, ,The assembly process on site workshop, The Process of transport from location to location workshop, The Process of transport around test site, Compactness of construction, Tendence/Tretment and Replacement of components (Table 2). The seventh categories are compared, it is seen that the sixth categories showed an excess of W2KDS. The most intersting things shown in the charactesitic of transportation from location to location workshop (transport between cities), we can see the W2KDS $80 \%$ more eaiser and more simple, and the characteristic replecement of components shows $70 \%$ more easier than Water Whell Permanent System. This is the solution of the problems experienced by Water Whell Permanent System.

Table 2. W2KDS advantages compared to the water wheel permanent system

\begin{tabular}{lc}
\hline \multicolumn{1}{c}{ The characteristics of } & Percentage of W2KDS advantages \\
\hline - Process created & $10 \%$ easier \\
- The assembly Process & $20 \%$ easier \\
- The process of transport between cities & $80 \%$ easier and more simple \\
- The process of transport around test & 50 more easily \\
site & \\
- Compactness of construction & \\
- Tendence/Treatment & Relatively the same as water wheel permanent \\
- Replacement of components & $50 \%$ easier \\
& $70 \%$ easier \\
\hline
\end{tabular}

\subsection{Efficiency of the W2KDS Prime Mover}

Efficiency of the W2KDSprime mover for the four ratio of discharge water as described Table 3.

Table 3: Efficiency of the W2KDS

\begin{tabular}{cccc}
\hline Discharge Ratios (\%) & $\begin{array}{c}\text { Potential Power } \\
\text { (Watt) }\end{array}$ & $\begin{array}{c}\text { Real Power } \\
\text { (Watt) }\end{array}$ & Efficiency (\%) \\
\hline 24 & 1760 & 0 & 0 \\
50 & 2940 & 1530 & 52 \\
75 & 4415 & 3270 & 74 \\
100 & 5890 & 4615 & 79 \\
\hline
\end{tabular}

Furthermore, the trend of the influence of the discharge ratio on the W2KDS prime mover efficiency can be explained by the following curve (figure 9). It can be analyzed that the discharge ratio $0-24 \%$ turbine efficiency reaches the lowest point, meaning that at that interval W2KDS has not been able to produce effective power, this is called discharge start. Starting from the $24 \%$ to $75 \%$ discharge ratio the turbine efficiency increase is significantly increased, indicating W2KDS is quite sensitive in terms of the increase in power generation rise due to the addition of water discharge. Furthermore, from the change of the $75 \%$ to $100 \%$ 
discharge rate resulting in a slightly upward trend and stable tendency, this situation explains that W2KDS is beginning to be less sensitive to changes in the above-mentioned $75 \%$ discharge rate. However, the highest efficiency of the W2KDS of $79 \%$ occurs at a $100 \%$ discharge ratio, that is the finding that can be used as a measure of achievement from W2KDS as a prime mover.

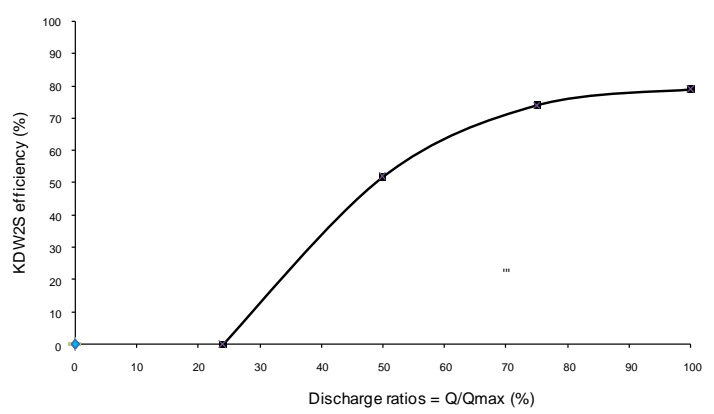

Fig. 9. Efficiency curve of W2KDS

\subsection{Efficiency Of The Transmission System W2KDS}

Testing the efficiency of transmission system W2KDS do with braking mechanisms in order to find out the torque and torque raised runner so that occur at an intermediate shaft. The efficiency of transmission system can be found by comparing the power axis between rice milling with power raised runner wheels as described Table 4. The interesting thing is shown at discharge ratio $100 \%$, the discharge it produces efficiency of W2KDS transmission systems $94 \%$. This result shows the quality transmission are made is can be proud of.

Table 4. Efficiency of W2KDS transmission system for four discharge ratios

\begin{tabular}{cccc}
\hline $\begin{array}{c}\text { DischargeRatios } \\
(\%)\end{array}$ & $\begin{array}{c}\text { W2KDS Shaft Power } \\
\text { (Watt) }\end{array}$ & $\begin{array}{c}\text { Rice Milling Shaft } \\
\text { Power (Watt) }\end{array}$ & $\begin{array}{c}\text { W2KDS Transmission } \\
\text { System Efficiency }(\%)\end{array}$ \\
\hline 24 & 0 & 0 & 0 \\
50 & 1530 & 950 & 62 \\
75 & 3270 & 2480 & 87 \\
100 & 4615 & 4080 & 94 \\
\hline
\end{tabular}

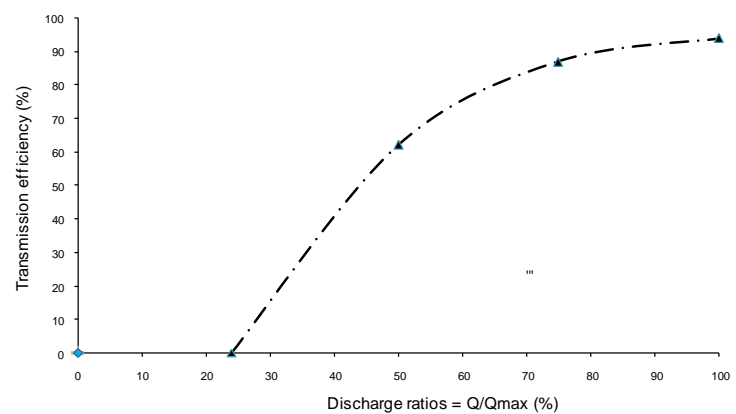

Fig. 10. Efficiency curve of transmission system for four discharge ratios. 


\subsection{Productivity of Rice Milling}

Conventional rice milling operated the community always uses motor diesel fuel as prime mover of rice milling, thus production costs relatively expensive especially when rice milling is in the village a far location of fuel injection station. W2KDS into a proper alternative to serve as the prime mover of the early rice milling operations cost advantages are very cheap because it does not require fuel oil as well as suitable to be operated at the corner of village even in the isolated villages. W2KDS became a model to facilitate community Mamping Village in South Solok to do rice milling. The results and observations known to the productivity of rice milling is described table 5. Rice milling productivity trend can be explained by figure 11. The graph shows that increased productivity is directly proportional/linear with the addition of discharge. Productivity at discharge ration $100 \%$ for 5 minutes is $12 \mathrm{~kg}$ and for 1 hour is $144 \mathrm{~kg}$, the production of rice milling is quite satisfactory.

Table 5 . Productivity of rice milling for four discharge ratios

\begin{tabular}{cccc}
\hline $\begin{array}{c}\text { Discharge } \\
\text { Ratios (\%) }\end{array}$ & Production Time (minutes) & Rice Produced (kg) & $\begin{array}{c}\text { Rice Milling } \\
\text { Productivity }(\mathrm{kg} / \mathrm{h})\end{array}$ \\
\hline 24 & 5 & 0 & 0 \\
50 & 5 & 4,5 & 54,4 \\
75 & 5 & 8 & 96 \\
100 & 5 & 12 & 144 \\
\hline
\end{tabular}

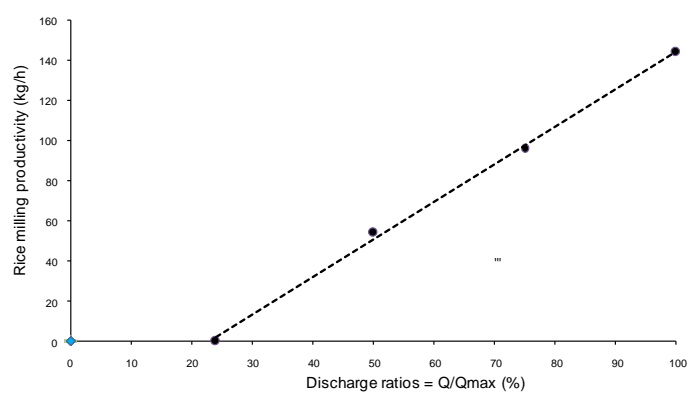

Fig. 11. Productivity of rice milling machine

\section{Conclusions}

Components of the prime moverW2KDS designed from materials that can be dismantled pairs, connection between the runner with the shaft using the connection bolts and pegs, with a system like that is very helpful at all facilitate the process of transporting and installation on site testing

From the results of testing the efficiency of the prime moverW2KDS known relative efficiency trend is constant for each debit change starts from $75 \%$ debit percentage to $100 \%$. On a percentage of $100 \%$ discharge or 100 litre/sec maximum efficiency is obtained by registration $79 \%$ and productivity of rice milling $144 \mathrm{~kg} /$ hour. Thus the prime moverW2KDS quality rice milling built quite satisfying and can be proud of. 


\section{Acknowledgements}

The authors would like to thank both Sekolah Tinggi Teknologi Industri (STTIND) Padang, and People of Mamping Village and all those who have contributed.

\section{References}

[1] Asep N. B., 2015, Rancang Bangun Kincir Air Sistem Knock-Down Untuk Pemenuhan Energi Listrik Bagi Masyarakat Terisolir DI Sumatera Barat, Jurnal Teknik Mesin ITP Padang, ISBN 2089-4880 Vol 5 (2) : 13-25.

[2] Binaya, K.C., dan Bhola, T, 2012, Pressure Distribution At Inner Surface Of Selected Pelton Bucket For Pico Hydro. Kathmandu Univercity Journal Of Science, Engineering And Technology, Vol. 5, No. II, September, pp 42-50.

[3] Choi, Y.D, 2010, Performance Improvement Of A Cross Flow Turbine By Air Layer Effect, $25^{\text {th }}$ IAHR Symposium on Hydraulic Machinery and Systems IOP Publishing IOP Conf, Series: Earth and Environmental Science 12.

[4] Chuenchoopklin, S, 2010,Development of Piko -hydropower Plant for Farming Village in Upstream Watershed, Thailand,International Journal Of Environmental Sciences, ISSN 0976 4402. Vol 1 (3).

[5] Church, Austin H, 1986,Pompa Dan Blower Sentrifugal. Penerbit Erlangga, Jakarta.

[6] Departemen Pendidikan dan Kebudayaan Republik Indonesia, 2008,Kamus Besar Bahasa Indonesia, Jakarta.

[7] Dewan Riset Nasional, 2010, Agenda Riset Nasional, Dewan Riset Nasional, Jakarta.

[8] Dietzel, F,1988,Turbin, Pompa Dan Kompresor. Penerbit Erlangga, Jakarta.

[9] Dirjen LPE-DESDM, 2010,Undang-undang Republik Indonesia Nomor 30 Tahun 2010 Tentang Energi, Dirjen LPE-DESDM. Jakarta.

[10] Enoh, R.M,2010,Perencanaan dan Pembuatan Turbin Cross Flow dengan Kapasitas $38 \mathrm{~kW}$ untuk PLTMH Batu Sanggan, Kabupaten Kampar, Propinsi Riau.Laporan Penelitian, MSTUGM,Jogjakarta.

[11] European Small Hydropower Association, 1998,A Layman's Guidebook on How to Develop a Small Hydro Site, $2^{\text {nd }}$ Edition, London.

[12] Fiala, J. dan Taraba, B, 2010,Utilization Of Measuring Stand For Piko Hydro Power Plants, European Journal of Scientific Research, ISSN 1450-216X. Vol 4 (3) : 354-372.

[13] Hairussa, J. dan Soenoko, R, 2010,Performance And Flow Characteristics Latitude Of Nosel In Turbine Sudus Second Level,Journal of Economics and Engineering, ISSN: 2078-0346, No. 4, December, 2010

[14] Harvey, A,1993,Micro-Hydro Design Manual,ITDGPublishing $1^{\text {st }}$ Edition, London

[15] Hoesein A.A. dan Montarcih, L, 2011,Design Of Micro Hydro Electrical Power At Brang Rea River In West Sumbawa Of Indonesia,Journal of Applied Technology in Environmental Sanitation. Vol 1 (2) : 177-183.

[16] Ho-Yan, B.P, 2011,Tesla Turbine For Pico Hydro Applications,Guelph Engineering Journal, ISSN: 1916-1107,Vol 2 (4) :1-8.

[17] Ho-Yan, B.P, 2012,Design Of Pico-Hydro Turbine or Rural Elecyrification In Cameroon,Australian Journal of Basic and Applied Sciences, ISSN 1991-8178, Vol 2(4):12091222.

[18] Jagdis, 2005,Hydraulic Machine, Metropolitan Book Co PrivateLtd., New Delhi.

[19] Klemm, T., Gabi, M. and Heraud, J.N, 2010,Application Of A Cross Flow Fan As Wind Turbine,Journal of Computational and Applied Mechanics, Vol. 8., No. 2.

[20] Mosher, A.T, 1998, Menggerakkan dan Membangun Pertanian, CV. Yasaguna, Jakarta.

[21] Williamson, S.J. Stark, B.H. and Booker, J.D, 2011, Low Head Piko Hidro Turbine Selection Using a Multi-Criteria Analysis,Paper in World Renewable Energy Congress 2011-Sweden. 